\title{
Pencapaian hasil belajar melalui model problem-based learning
}

\author{
Dewi Qurrotul A'yun \\ SD Muhammadiyah Nitikan Yogyakarta. Jalan Kranon Nitikan No.UH VI, RT.45/RW.11, Kota Yogyakarta, 55162, Indonesia \\ dq.ayun93@gmail.com \\ * corresponding author
}

\section{ARTICLE INFO}

Keywords

Model pembelajaran

PBL

Hasi belajar IPA

Sistem peredaran darah

\begin{abstract}
Penelitian ini bertujuan untuk meningkatkan hasil belajar IPA di Kelas VA-2 SD Muhammadiyah Nitikan pada materi Sistem Peredaran Darah Manusia setelah pembelajaran Model Problem-Based Learning, dan untuk mendeskripsikan proses berlangsungnya pembelajaran IPA pada materi Sistem Peredaran Darah Manusia dengan menggunakan Model Problem-Based Learning di Kelas VA-2 SD Muhammadiyah Nitikan Yogyakarta. Penelitian ini merupakan penelitian tindakan kelas (PTK) kolaboratif dimana ada kolaborasi (kerjasama) antara praktisi (guru, kepala sekolah, teman sejawat, siswa dan lain-lain) dan peneliti (dosen/ widyaiswara) dalam pemahaman, kesepakatan tentang permasalah, pengambilan keputusan yang akhirnya melahirkan kesamaan tindakan (action). Data yang diambil dalam penelitian ini ada 3: (1) Data hasil belajar IPA selama siklus I; (2) Data hasil belajar IPA selama siklus II; dan (3) Data keterlaksanaan model pembelajaran yang diambil menggunakan lembar observasi guru dan lembar observasi siswa yang dinilai oleh kolaboran dimana bertindak sebagai observer selama kegiatan belajar mengajar berlangsung. Hasil penelitian menunjukkan bahwa perolehan nilai rata-rata meningkat dari 73 menjadi 82. Ketuntasan belajar meningkat dari $52,78 \%$ menjadi $75 \%$. Jadi dapat disimpulkan bahwa model pembelajaran Problem-Based Learning (PBL) dapat meningkatkan hasil belajar IPA pada siswa kelas VA-2 SD Muhammadiyah Nitikan Yogyakarta.
\end{abstract}

This is an open access article under the CC-BY-SA license.

\section{PENDAHULUAN}

Perkembangan era globalisasi yang begitu pesat, menumbuhkan banyak persaingan di berbagai bidang kehidupan. Hampir meliputi di seluruh aspek ekonomi, politik, sosial, budaya, pertahanan, dan keamanan dan tentu saja di dunia pendidikan, terkhusus pendidikan IPA. Dalam rangka menghadapi tantangan dunia global ini, sangat dibutuhkan lahirnya generasi sumber daya manusia yang memiliki mutu tinggi. Usaha yang diambil, salah satunya adalah dengan cara meningkatkan mutu pendidikan di Indonesia.

Peningkatan mutu pendidikan di Indonesia dapat dilakukan dengan cara mengoptimalkan proses belajar mengajar di dalam kelas. Upaya tersebut diharapkan dapat menghasilkan siswa yang memiliki kecerdasan optimal. Proses belajar mengajar, yang bertujuan untuk memberikan pemahaman yang baik pada siswa haruslah sesuai dengan metode pembelajaran yang digunakan. Diharapkan dengan menggunakan metode yang tepat, siswa dapat dengan mudah memahami isi pembelajaran yang disampaikan oleh guru. 
Salah satu mata pelajaran yang diajarkan di sekolah adalah Ilmu Pengetahuan Alam. Ilmu Pengetahuan Alam atau biasa disingkat dengan IPA, merupakan salah satu mata pelajaran inti, dimana hasil belajar daripada mata pelajaran ini akan sangat diperhitungkan. Hal ini disebabkan karena IPA berkaitan dengan cara mencari tahu tentang gejala alam secara sistematis. IPA berhubungan dengan cara mencari tahu tentang alam secara sistematis, sehingga IPA bukan hanya penguasaan kumpulan sistematis dan IPA bukan hanya penguasaan kumpulan pengetahuan yang berupa fakta-fakta, konsep-konsep atau prinsip-prinsip saja, tetapi juga merupakan suatu proses penemuan (Rakhmawati et al., 2013; Sulistyorini, 2007). Proses pembelajaran IPA menekankan pada pemberian pengalaman langsung kepada siswa untuk dapat mengembangkan kompetensi agar peserta didik mampu menjelajahi dan memahami alam sekitar secara ilmiah. Pembelajaran IPA di SD dimaksudkan agar siswa mempunyai pengetahuan, gagasan dan konsep yang terorganisasi tentang alam sekitar, yang diperoleh dari pengalaman melalui serangkaian proses ilmiah antara lain penyelidikan, penyusunan dan penyajian gagasan-gagasan. Pada prinsipnya, mempelajari IPA sebagai cara mencari tahu dan cara mengerjakan atau melakukan dan membantu siswa untuk memahami alam sekitar secara lebih mendalam (Depdiknas dalam Suyitno, 2007: 7).

Pelajaran IPA seharusnya merupakan pelajaran yang menyenangkan, karena berkaitan erat dengan kehidupan siswa sehari-hari. Akan tetapi apa yang terjadi di lapangan belum seperti apa yang diharapkan. Hal ini dikarenakan penggunaaan model dan metode yang kurang tepat dalam mengajar. Kebanyakan guru memberikan pelajaran pada siswa terfokus pada aspek ingatan dan pemahaman saja, dengan tujuan sekedar untuk dapat lulus dari ujian nasional semata. Padahal pembelajaran IPA yang demikian tentu saja akan menciptakan suasana kelas yang monoton, statis, dan cenderung membosankan. Oleh sebab itu, diperlukan peran guru dalam menentukan model pembelajaran yang tepat, yang diharapkan dapat meningkatkan hasil belajar dan keterampilan siswa. Seorang pendidik harus bisa mengarahkan dan menggali potensi yang ada pada diri siswa, sehingga siswa mampu untuk mengembangkan keterampilan-keterampilan tertentu diantaranya adalah keterampilan berpikir kritis.

Sumber belajar yang terbatas pada guru dan buku paket saja, juga akan semakin menghambat kreativitas siswa untuk berkembang. Siswa menjadi tidak terbiasa untuk mengkonstruk sendiri pengetahuannya. Hal ini menyebabkan siswa menjadi kurang aktif saat kegiatan belajar mengajar di dalam kelas, sehingga mereka jarang untuk bertanya. Didukung juga dengan model pembelajaran yang digunakan kurang mendorong dan melibatkan siwa untuk berpartisipasi secara aktif selama kegiatan belajar mengajar. Padahal untuk dapat menambah pemahaman siswa, sangat diperlukan adanya partisipasi aktif siswa selama proses belajar mengajar berlangsung.

Hasil observasi yang dilakukan oleh peneliti selama proses belajar mengajar di kelas VA-2 SD Muhammadiyah Nitikan juga mengungkapkan hal yang tidak jauh berbeda. Siswa cenderung malas, tidak semangat untuk belajar, ingin mencari suasana belajar yang lain dikarenakan kegiatan belajar mengajar di dalam kelas kurang melibatkan siswa untuk dapat mendalami materi. Kegiatan pembelajaran yang dilakukan selama ini adalah dimana guru menerangkan materi pelajaran di depan kelas dengan metode ceramah, dan siswa dituntut untuk menjadi pendengar yang baik. Tak jarang banyak siswa yang justru mencari kegiatan lain seperti mengobrol dengan teman, membaca komik, atau malah tidur untuk mengusir kebosanan dalam belajar. Hal ini dikarenakan siswa kekurangan peran di dalam proses kegiatan belajar.

Dampak nyata dari kegiatan belajar mengajar selama observasi, menunjukkan bahwa hasil belajar IPA masih rendah. Terbukti dengan hasil ulangan bab sebelumnya (Sistem pernapasan dan pencernaan manusia) yang ternyata masih mencapai nilai rata-rata kelas 65 , padahal untuk mencapai KKM mata pelajarn IPA, dibutuhkan rata-rata nilai 75. Hal ini dikarenakan kebanyakan siswa yang cenderung kurang aktif, kurang memperhatikan penjelasan guru, model mengajar guru yang kurang menarik, dan konsep materi yang terlalu sukar untuk dipahami siswa.

Situasi tersebut harus ditanggapi serius oleh pendidik untuk mencari alternatif mengenai model pembelajaran yang sesuai dan menarik agar dapat memotivasi siswa untuk lebih kreatif dan percaya diri serta mendorong untuk berpikir kritis siswa. Menurut Patmawati (2011), dari hasil penelitiannya menguraikan bahwa berpikir kritis akan mengakibatkan siswa membuat keputusan yang tepat, cermat, sistematis, logis, dan mempertimbangkan berbagai sudut pandang. Kurangnya kemampuan ini, dapat menyebabkan siswa melakukan kegiatan tanpa mengerti tujuan dan alasan untuk melaku- 
kannya. Oleh karena itu, kegiatan belajar mengajar di sekolah harus dapat membekali para siswa dengan kemampuan dan keterampilan dalam memahami, menganalisis, dan mengolah informasi.

Bertolak dari uraian permasalahan tersebut, solusi yang ditawarkan oleh peneliti adalah penggunaan model pembelajaran PBL (Problem-Based Learning) Alasan pemilihan model ini adalah karena model pembelajaran tersebut memiliki kelebihan-kelebihan terkait bagaimana membuat siswa dapat berperan aktif selama pembelajaran, sehingga memicu daya keterampilan berpikir siswa untuk berkembang. Problem-Based Learning dilandasi oleh perspektif kognitif-konstruktivisme dimana pelajar dengan umur berapa pun dapat terlibat secara aktif dalam proses mendapatkan informasi dan mengkonstruksi pengetahuannya sendiri (Arends, 2012).

Ciri khas Problem-Based Learning terletak pada kemampuan mengaitkan antara keterampilan dengan bidang ilmu, keterampilan berpikir kritis, berkolaborasi, berdiskusi, berargumentasi, mencari informasi, mendapatkan dan mengevaluasi data, menginterpretasikan dan mengkomunikasikan hasil diskusi. Problem-Based Learning dapat membentuk interpersonal skill, seperti bekerja dalam tim, saling mengajari, memimpin, bernegosiasi, bekerja dengan baik dengan orang-orang dari berbagai latar belakang budaya yang berbeda. Model Problem-Based Learning dapat juga memberikan kesempatan kepada siswa untuk bereksplorasi sehingga siswa mampu untuk berpikir kritis, analitis, sistematis, dan logis dalam menentukan alternatif pemecahan masalah (Sanjaya, 2016, p. 210).

Adapun materi yang digunakan dalam penelitian ini adalah "Sistem Peredarah Darah pada manusia". Materi ini merupakan salah satu materi yang diberikan pada jenjang pendidikan SD. Materi pokok "Sistem Peredarah Darah pada Manusia" merupakan materi yang mengandung berbagai permasalahan nyata yang akan menuntut siswa untuk lebih mengembangkan segenap kemamuan berpikirnya untuk penyelesaian masalah-masalah yang terkait dengan materi tersebut. Siswa dituntut untuk aktif selama kegiatan belajar mengajar di dalam kelas, maupun dalam pengamatan di luar kelas untuk lebih dapat memahami dan memberikan solusi terhadap permasalahan-permasalahan nyata di kehidupan siswa sehari-hari.

Jenis penelitian ini adalah penelitian tindakan kelas (PTK). Penelitian tindakan kelas adalah suatu rancangan penelitian yang dirancang khusus untuk meningkatkan kualitas pembelajaran di dalam kelas. Guru yang melakukan penelitian tindakan kelas berperan ganda, yaitu sebagai guru dan sebagai peneliti. Subjek dalam penelitian ini adalah siswa Kelas VA-2 SD Muhammadiyah Nitikan Yogyakarta tahun ajaran 2016/2017 sebanyak 36 siswa, yang terdiri dari laki-laki sebanyak 21 orang dan perempuan sebanyak 15 orang. Sumber data diperoleh dari hasil belajar setelah proses pembelajaran tentang Sistem pernapasan dan pencernaan manusia. Hasil ulangan yang diperoleh hanya mencapai rata-rata 65, sedangkan KKM untuk mata pelajaran IPA saat ini adalah 75. Ketika ditanyakan pada siswa, ternyata hampir $79 \%$ siswa menjawab kesulitan.

\section{METODE}

Dalam penelitian ini menggunakan kerjasama (kolaborasi) dengan teman sejawat, artinya peneliti dan teman sejawat masing-masing menpunyai peranan dan tanggung jawab yang saling membutuhkan dan saling melengkapi untuk mencapai tujuan. Pihak yang melakukan tindakan adalah peneliti sebagai guru, sedangkan yang diminta melakukan pengamatan terhadap berlangsungnya tindakan adalah teman sejawat.

Proses pelaksanaan penelitian tindakan kelas dapat dirujuk dari beberapa model, tetapi yang digunakan dalam penelitian ini adalah dengan menggunakan model siklus yang dikemukakan oleh Kemmis \& Taggart yang terdiri atas: planning (menyusun perencanaan), acting (melaksanakan tindakan), observing (melaksanakan pengamatan), dan reflecting (melakukan refleksi), hasil refleksi ini kemudian dipergunakan untuk memperbaiki perencanaan berikutnya. Secara sederhana, alur pelaksanaan tindakan kelas menurut (Arikunto et al., 2010) disajikan dalam diagram alir pada Gambar 1. 


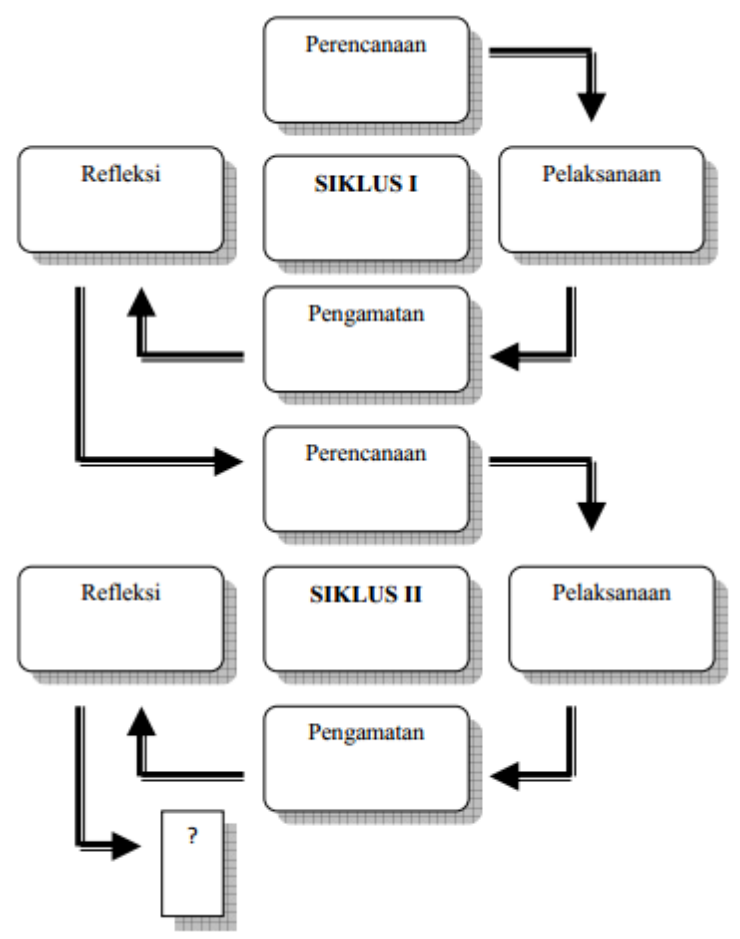

Gambar 1. Diagram Alir Penelitian Tindakan Kelas

\section{HASIL DAN PEMBAHASAN}

\section{Pembelajaran IPA Melalui PBL}

Pengamatan terhadap tindakan siklus I dilakukan observer yang meliputi aktivitas guru dan siswa. Pengamatan dilakukan selama proses pembelajaran berlangsung sampai pembelajaran selesai. Hasil pengamatan terhadap aktivitas guru di siklus I menunjukkan bahwa guru belum sepenuhnya melaksanakan model pembelajaran Problem-Based Learning (PBL) dengan baik. Guru belum memberikan kesempatan kepada siswa untuk saling berdiskusi antaranggota kelompok. Siswa langsung diminta menjawab pertanyaan di lembar kerja. Artinya, guru belum maksimal dalam membantu investigasi mandiri dan kelompok dalam PBL. Guru belum memberi kesempatan kepada setiap siswa untuk menjawab pertanyaan yang diajukan oleh guru. Guru juga belum berhasil mengarahkan siswa untuk aktif bertanya dan menanggapi presentasi kelompok lain. Kerja kelompok belum berjalan dengan baik karena guru tidak membimbing siswa melakukan pembagian tugas pada setiap anggota kelompok.

Hasil pengamatan terhadap aktivitas siswa pada siklus I menunjukkan bahwa belum ada siswa yang mengemukakan pendapatnya yang berhubungan dengan materi yang dipelajari. Siswa masih mengalami kesulitan dalam melakukan kegiatan eksperimen. Hal ini dikarenakan siswa belum memahami penjelasan guru tentang langkah kegiatan eksperimen. Ketika guru menjelaskan masih ada siswa yang bermain sendiri dan tidak memperhatikan penjelasan guru dengan baik. Kerja kelompok belum berjalan dengan baik karena masih ada siswa yang pasif dalam diskusi bahkan ada yang asyik bermain atau berbicara dengan temannya. Siswa masih malu untuk bertanya dan mempresentasikan hasil diskusinya. Dan siswa masih mengalami kesulitan dalam menyimpulkan hasil kegiatan eksperimen yang dilakukan. Beberapa kekurangan pada siklus I tersebut menyebabkan hasil belajar siswa ranah kognitif belum maksimal.

Hasil penilaian di akhir siklus I menunjukkan bahwa siswa yang sudah mencapai KKM sebanyak 19 siswa $(52,78 \%)$ dan siswa yang belum mencapai KKM sebanyak 17 siswa $(47,22 \%)$. Nilai ratarata kelas pada siklus I adalah 73. Nilai tertinggi yang diperoleh siswa adalah 86 dan nilai terendah 56. Pencapaian nilai siswa dalam kegiatan siklus I dapat didistribusikan dalam kriteria seperti pada Tabel 1. 
Berdasarkan Tabel 1, dapat dilihat bahwa nilai siswa berada pada kriteria gagal (kurang dari 65) sejumlah 6 siswa yaitu 16,67 \% dari keseluruhan siswa. Siswa yang mencapai kriteria kurang (6569) sejumlah 3 siswa atau sekitar 8,3\%. Siswa yang mencapai kriteria cukup (70-74) sejumlah 9 siswa atau $25 \%$. Kriteria baik (75-80) berjumlah 12 siswa atau 33,33\%. Siswa yang memperoleh nilai sangat baik (lebih dari 80) ada 6 siswa. Rata-rata nilai siswa sudah terletak pada kategori baik (75-80) sebesar 33,33\%. Gambaran pencapaian prestasi belajar IPA siswa kelas VA-2 SD Muhammadiyah Nitikan pada siklus I dapat disajikan dalam Gambar 2.

Tabel 1. Kriteria Hasil Tes IPA Siklus I

\begin{tabular}{cccc}
\hline Skor & Kriteria & Jumlah & Persentase \\
\hline$>80$ & Sangat baik & 6 & $16,67 \%$ \\
$75-80$ & Baik & 12 & $33,33 \%$ \\
$70-74$ & Cukup & 9 & $25 \%$ \\
$65-69$ & Kurang & 3 & $8,3 \%$ \\
$<65$ & Gagal & 6 & $16,67 \%$ \\
\hline
\end{tabular}

\section{Grafik Kriteria Hasil Tes Siklus I}

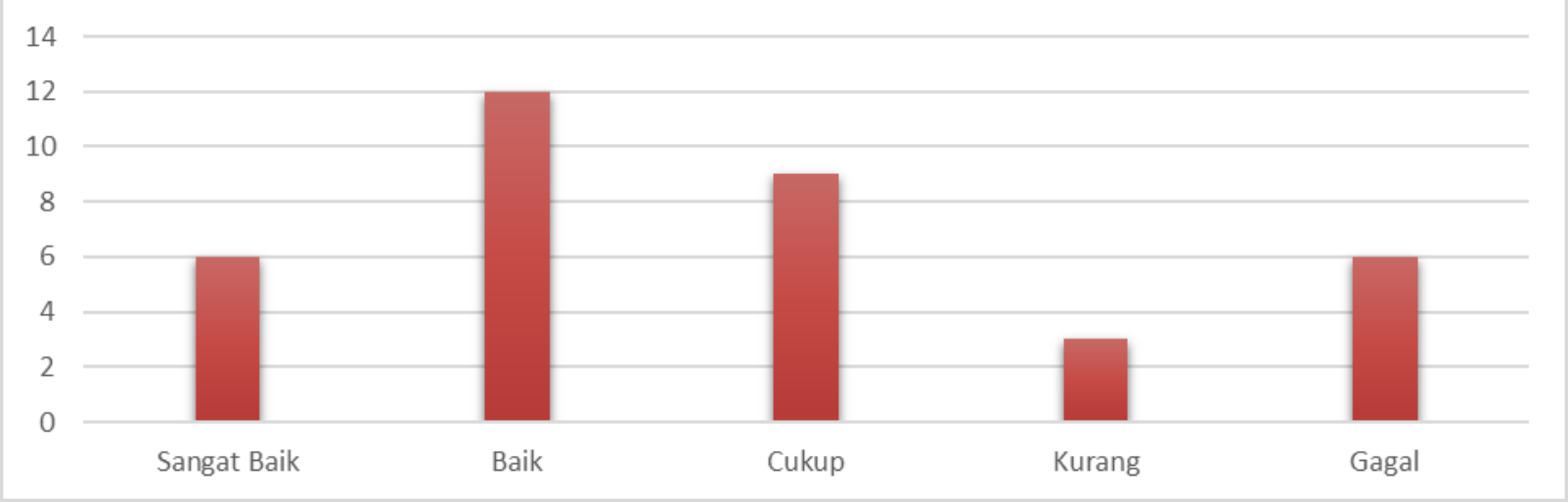

Gambar 2. Grafik Kriteria Hasil Tes IPA Siklus I

Dari Gambar 2 dapat disimpulkan bahwa setelah dilakukan tindakan siklus I terjadi peningkatan hasil belajar siswa. Nilai rata-rata kelas yang pada saat pra tindakan sebesar 69, pada siklus I sudah meningkat menjadi 73. Persentase ketuntasan belajar siswa yang mencapai KKM juga mengalami peningkatan. Pada saat pratindakan, siswa yang mencapai KKM sebesar 16,67\% (6 siswa) sedangkan pada siklus I sudah mencapai 52,78\% (19 siswa).

\section{Refleksi Siklus I}

Refleksi dilakukan untuk mengetahui tingkat keberhasilan tindakan pada siklus I. Hasil tes belajar siswa di siklus I menunjukkan siswa yang sudah mencapai $K K M \geq 75$ masih sebesar $52,78 \%$. Hal ini belum memenuhi kriteria keberhasilan penelitian yaitu persentase siswa yang mencapai nilai KKM minimal 75\%. Pada siklus I nilai rata-rata kelas yaitu 69, juga belum memenuhi kriteria ketuntasan minimal (KKM) IPA yaitu $\geq 75$. Kemudian diambil kesimpulan dari pertimbangan tersebut untuk melanjutkan penelitian ke siklus II.

Evaluasi dilakukan terhadap tindakan siklus I. Berdasarkan hasil observasi dan hasil tes belajar siswa, ditemukan beberapa kekurangan dalam tindakan siklus I. Kekurangan-kekurangan tersebut perlu diperbaiki pada tindakan di siklus berikutnya. Oleh karena itu perencanaan tindakan dilakukan pada siklus II dengan mempertimbangkan kekurangan selama proses pembelajaran siklus I. Peneliti membuat format dalam bentuk tabel untuk memudahkan membandingkan antara apa yang akan dilakukan dalam siklus berikutnya. Tabel berikut ini merupakan kekurangan yang masih ditemui pada siklus I dan perencanaan yang dilakukan pada siklus II.

Selama tindakan siklus II dilaksanakan, dilakukan pengamatan terhadap aktivitas guru dan siswa. Pengamatan difokuskan untuk mengetahui peningkatan prestasi belajar siswa yang terjadi pada siklus II. Kegiatan pengamatan dilakukan selama proses pembelajaran sampai pembelajaran selesai. Hasil pengamatan siklus II adalah sebagai berikut. Guru sudah memperbaiki kekurangan-kekurangan yang dilakukan dalam kegiatan pembelajaran siklus I pada pembelajaran siklus II. Guru sudah 
memberi kesempatan setiap siswa untuk menjawab pertanyaan guru dengan membagi giliran ke setiap siswa. Setiap siswa harus memberi jawaban atas pertanyaan guru semampunya. Guru membantu siswa melakukan pembagian tugas dalam kelompok sehingga setiap siswa terlibat aktif dalam kerja kelompok. Guru membimbing kelompok yang mengalami kesulitan dan memberi motivasi kepada siswa yang pasif dengan memberikan pertanyaan pancingan agar lebih aktif, sehingga diskusi menjadi hidup. Diharapkan siswa lebih aktif dalam berdiskusi. Guru mendemonstrasikan contoh penggunaan alat dan bahan praktikum. Bahkan guru menunjukkan langkah-langkah menggunakan alat dan bahan praktikum secara terperinci. Guru memberikan pertanyaan pancingan dalam membimbing siswa membuat kesimpulan hasil percobaan. Pertanyaan pancingan ini sangat membantu siswa dalam membuat kesimpulan secara tepat. Guru juga memberikan kesempatan semua kelompok untuk secara bergiliran menyampaikan pendapatnya.

Tabel 2. Refleksi Siklus I dan Rencana Perbaikan dilakukan pada siklus II

\begin{tabular}{|c|}
\hline Refleksi Siklus I \\
\hline $\begin{array}{l}\text { Guru belum memberi kesempatan merata kepada setiap } \\
\text { siswa untuk menjawab pertanyaan. (Fase } 1 \text { : Memberika } \\
\text { orientasi tentang permasalahannya kepada peserta didik) }\end{array}$ \\
\hline $\begin{array}{l}\text { Siswa belum melakukan eksperimen dengan baik karena } \\
\text { belum memahami langkah eksperimen. (Fase 1: } \\
\text { Memberikan orientasi tentang permasalahannya kepada } \\
\text { peserta didik) }\end{array}$ \\
\hline
\end{tabular}

Guru belum memberikan kesempatan kepada siswa untuk saling berdiskusi antaranggota kelompok. Siswa langsung diminta menjawab pertanyaan di lembar kerja. Artinya, guru belum maksimal dalam memotivasi siswa untuk aktif dalam diskusi dalam PBL (Fase 2: Mengorganisasikan peserta didik untuk meneliti)

Kerja kelompok atau diskusi belum berjalan dengan baik. Masih terdapat beberapa siswa yang pasif dan asyik bermain sendiri ketika diskusi kelompok. Bahkan ada kelompok yang menyerahkan pekerjaan kepada satu siswa saja. (Fase 2: Mengorganisasikan peserta didik untuk meneliti)

Guru belum membimbing siswa melakukan pembagian tugas pada setiap anggota kelompok masih ada beberapa siswa yang pasif dan bermain sendiri. (Fase 3: Membantu investigasi mandiri dan kelompok.)

Siswa masih malu menyampaikan pendapat dan tanggapan terhadap kegiatan yang dilakukan. (Fase 4:

Mengembangkan dan mempresentasikan hasil karya dan memamerkan)

Siswa masih mengalami kesulitan dalam menyimpulkan hasil kegiatan yang dilakukan, sehingga membuat kesimpulan eksperimen kurang tepat.

(Fase 5: Menganilis dan mengevaluasi proses mengatasi masalah)

Rencana Perbaikan

Siswa diberi giliran bertanya dan menjawab pertanyaan secara berurutan. (Fase 1:

Memberikan orientasi tentang permasalahannya kepada peserta didik) Guru Menjelaskan petunjuk praktikum dengan lebih jelas dan siswa dilibatkan dalam demonstrasi penyusunan serta penggunaan alat. (Fase 1: Memberikan orientasi tentang permasalahannya kepada peserta didik) Siswa diberikan kesempatan untuk saling berdiskusi antaranggota kelompok.

Guru membimbing kelompok yang mengalami kesulitan.

(Fase 2: Mengorganisasikan peserta didik untuk meneliti)

Memberi motivasi kepada siswa yang pasif dengan memberikan pertanyaan pancingan agar lebih aktif, sehingga diskusi menjadi hidup. Siswa yang aktif berdiskusi diharapkan. (Fase 2: Mengorganisasikan peserta didik untuk meneliti)

Siswa dibimbing dalam Melakukan pembagian tugas dalam kerja kelompok agar tidak ada siswa yang pasif dan bermain sendiri.

(Fase 3: Membantu investigasi mandiri dan kelompok.)

Setiap kelompok diberi kesempatan untuk menyampaikan pendapatnya.

(Fase 4: Mengembangkan dan mempresentasikan hasil karya dan memamerkan)

Guru membimbing dan mengarahkan penentuan kesimpulan yang tepat di masingmasing kelompok.

(Fase 5: Menganilis dan mengevaluasi proses mengatasi masalah)

Berdasarkan pengamatan yang dilakukan pada siklus II terhadap aktivitas siswa, terlihat siswa sudah berani menjawab pertanyaan guru bahkan siswa tampak tidak takut bertanya kepada guru tentang hal-hal yang masih belum dimengerti. Kerja kelompok dan diskusi sudah berjalan dengan baik. Hampir semua siswa terlibat aktif dalam kerja kelompok. Hal ini dimungkinkan karena setiap siswa mendapat jatah tugas setelah dilakukan pembagian tugas dalam kelompok. Siswa sudah memahami langkah kegiatan eksperimen dengan baik sehingga tidak mengalami kesulitan dalam melakukan eksperimen. 
Demikian juga siswa sudah tidak malu lagi saat presentasi di depan kelas. Siswa sudah dapat membuat kesimpulan sendiri dari kegiatan praktikum yang dilakukan karena pertanyaan pancingan dari guru. Kegiatan pembelajaran pada siklus II sudah menunjukkan peningkatan terhadap aktivitas siswa dan guru. Hal ini memberi pengaruh terhadap hasil belajar siswa. Pada siklus II, telah terjadi peningkatan hasil belajar siswa dilihat dari hasil tes siklus II yang meningkat dibandingkan hasil tes pra tindakan dan hasil tes siklus I. Demikian juga persentase pencapaian KKM pada siklus II juga mengalami peningkatan.

Hasil penilaian di akhir siklus II menunjukkan bahwa siswa yang sudah mencapai KKM $\geq 75$ sebesar $75 \%$ atau sebanyak 27 siswa. Sedangkan siswa yang belum mencapai KKM tinggal 9 siswa. Nilai terendah pada siklus II ini adalah 60, sementara nilai tertinggi sudah mencapai 96. Hasil belajar IPA siswa kelas VA-2 SD Muhammadiyah Nitikan Yogyakarta rata-rata masuk pada kriteria sangat baik (86-100) yaitu sebesar 52,78\%. Untuk lebih jelasnya dapat dilihat pada Tabel 3.

Tabel 3. Kriteria Hasil Tes IPA Siklus II

\begin{tabular}{cccc}
\hline Skor & Kriteria & Jumlah & Persentase \\
\hline$>80$ & Sangat baik & 19 & $52,78 \%$ \\
$75-80$ & Baik & 8 & $22,22 \%$ \\
$70-74$ & Cukup & 5 & $13,89 \%$ \\
$65-69$ & Kurang & 3 & $8,33 \%$ \\
$<65$ & Gagal & 1 & $2,78 \%$ \\
\hline
\end{tabular}

Berdasarkan Tabel 3, dapat dilihat bahwa nilai siswa berada pada kriteria gagal (kurang dari 65) sejumlah 1 siswa yaitu 2,78 \% dari keseluruhan siswa. Siswa yang mencapai kriteria kurang (65-69) sejumlah 3 siswa atau sekitar 8,33\%. Siswa yang mencapai kriteria cukup (70-74) sejumlah 5 siswa atau $13,89 \%$. Kriteria baik (75-80) berjumlah 8 siswa atau 22,22\%. Siswa yang memperoleh nilai sangat baik (lebih dari 80) ada 19 siswa. Rata-rata nilai siswa sudah terletak pada kategori sangat baik (di atas nilai 80 ) sebesar $52,78 \%$. Gambaran pencapaian prestasi belajar IPA siswa kelas VA-2 SD Muhammadiyah Nitikan pada siklus II dapat disajikan dalam Gambar 3.

Berdasarkan Tabel 4 dapat disimpulkan bahwa nilai rata-rata kelas setelah dilakukan tindakan mengalami peningkatan dari kondisi awal pra tindakan 69 menjadi 73 pada siklus I dan 82 pada siklus II. Persentase pencapaian KKM juga mengalami peningkatan dari kondisi awal pratindakan $16,67 \%$ menjadi $52,78 \%$ pada siklus I dan $75 \%$ pada siklus II.

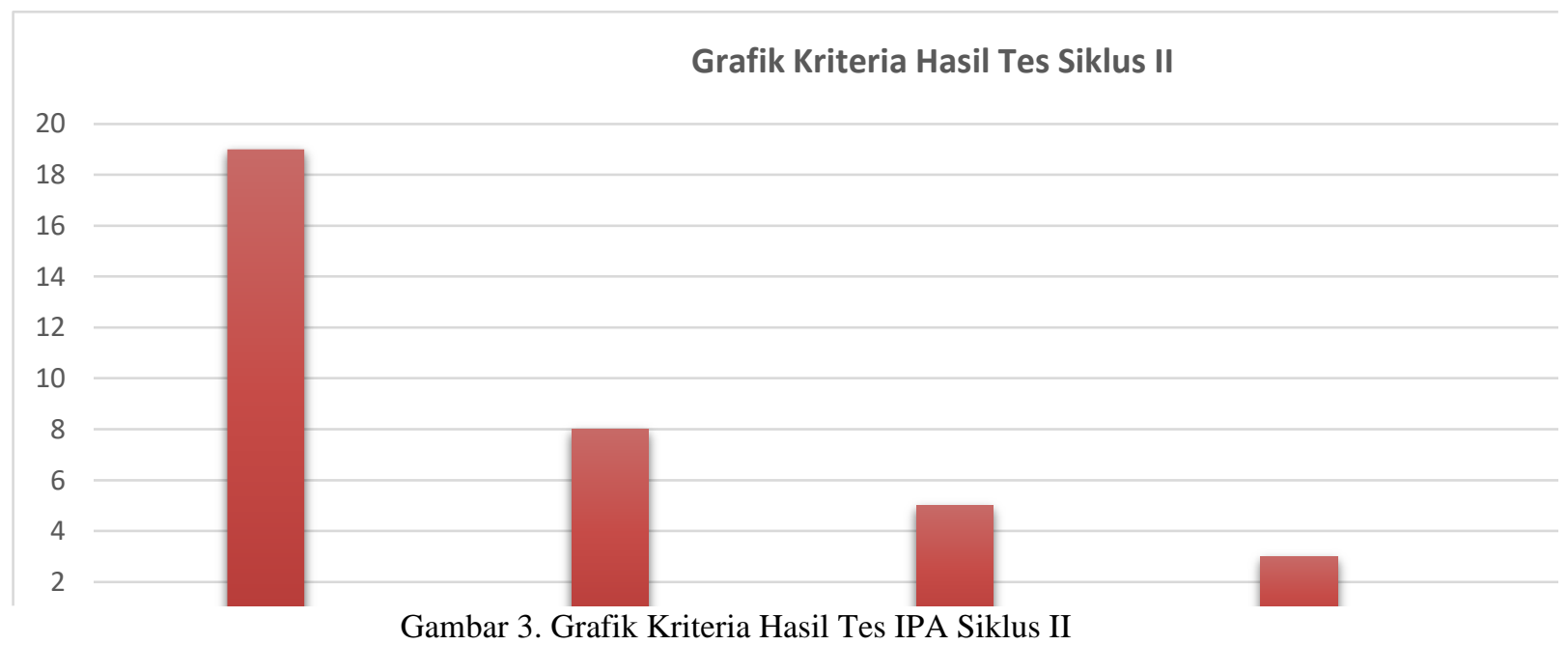

Berdasarkan data tersebut dapat dilihat bahwa pada siklus II terjadi peningkatan pada nilai ratarata kelas yang mencapai 82. Dari data tersebut, rata-rata kelas dalam siklus II ini sudah melebihi $K K M$ yaitu $\geq 75$. Sedangkan persentase siswa yang mencapai nilai $K K M \geq 75$ minimal $75 \%$ dari jumlah siswa, juga sudah terpenuhi. Persentase siswa yang mencapai KKM sebesar $75 \%$ atau sebanyak 27 siswa dari 36 siswa. Peningkatan hasil tindakan pada siklus I dan siklus II dapat dilihat pada Tabel 4. 
Tabel 4. Perbandingan Hasil Tes Pra Tindakan, Siklus I dan Siklus II

\begin{tabular}{|c|c|c|c|}
\hline Aspek yang diamati & Pra tindakan & Siklus I & Siklus II \\
\hline Nilai tertinggi & 77 & 86 & 96 \\
\hline Nilai terendah & 60 & 56 & 60 \\
\hline Nilai rata-rata & 69 & 73 & 82 \\
\hline Jumlah siswa yang belum mencapai KKM & 30 & 17 & 9 \\
\hline Jumlah siswa yang telah mencapai KKM & 6 & 19 & 27 \\
\hline Persentase siswa yang telah mencapai KKM & $16,67 \%$ & $52,78 \%$ & $75 \%$ \\
\hline
\end{tabular}

\section{Refleksi Siklus II}

Hasil observasi dan hasil tes pada siklus II menunjukkan bahwa tindakan pada siklus II sudah berjalan sesuai dengan yang diharapkan yaitu tercapainya nilai rata-rata kelas $\geq 75$ dan persentase nilai yang mencapai KKM sudah $\geq 75 \%$. Hasil yang diperoleh pada siklus II sudah memenuhi semua kriteria keberhasilan penelitian sehingga penelitian tindakan kelas ini diakhiri dan tidak perlu dilanjutkan ke siklus berikutnya.

\section{HASIL DAN PEMBAHASAN}

Berdasarkan nilai rata-rata di setiap akhir siklus kegiatan pembelajaran yang menggunakan model pembelajaran Problem-Based Learning (PBL), menunjukkan terjadi peningkatan hasil belajar IPA siswa kelas VA-2 SD Muhammadiyah Nitikan. Peningkatan nilai rata-rata kelas sebesar 9,00 dari 73 pada siklus I menjadi 82 pada siklus II. Persentase jumlah siswa yang mencapai nilai KKM atau dinyatakan tuntas belajar juga terjadi peningkatan sebesar $22,22 \%$, dari $52,78 \%$ pada siklus I menjadi $75 \%$ pada siklus II. Pada siklus I terdapat 17 siswa yang belum mencapai KKM, sedangkan pada siklus II tinggal 9 siswa yang belum mencapai KKM. Dapat dikatakan bahwa pada siklus II ada kenaikan 8 siswa yang telah mencapai KKM. Peningkatan hasil tindakan pada siklus I dan siklus II dapat dilihat pada Gambar 4.

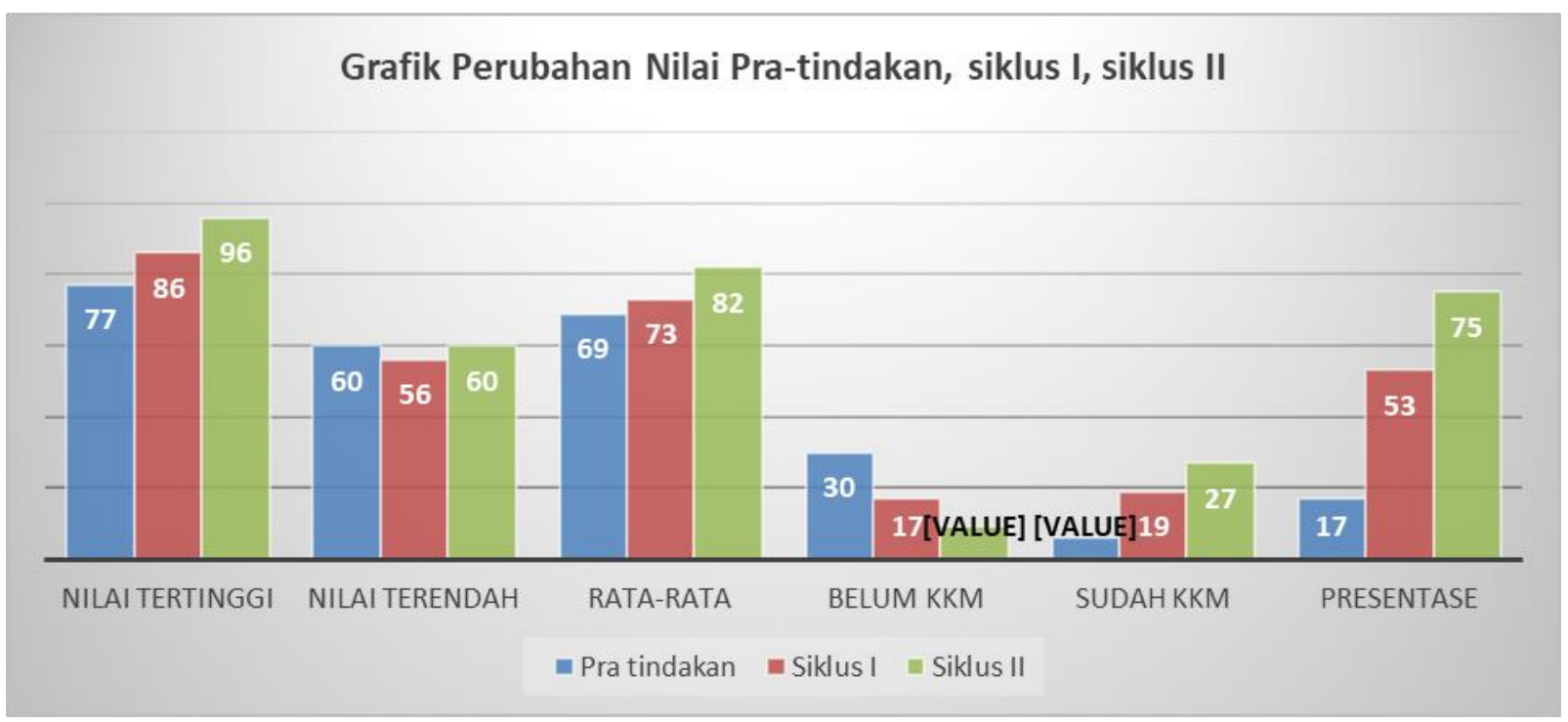

Gambar 4. Grafik Perubahan Nilai Pra-tindakan, siklus I, dan Siklus II

Peningkatan hasil belajar IPA terjadi sangat signifikan pada siklus II karena guru telah menerapkan 5 fase model pembelajaran PBL dalam pembelajaran IPA secara tepat. Fase-fase model pembelajaran PBL yang telah diterapkan dalam penelitian ini yaitu: (Fase 1) Memberikan orientasi tentang permasalahan kepada peserta didik; (Fase 2) Mengorganisasikan peserta didik untuk meneliti; (Fase 3) Membantu investigasi mandiri dan kelompok; (Fase 4) Mengembangkan dan mempresentasikan hasil karya dan memamerkan; dan (Fase 5) Menganalisis dan mengevaluasi proses mengatasi masalah.

Model pembelajaran Problem-Based Learning (PBL) pada siklus II lebih efektif jika dibandingkan pada siklus I karena guru sudah memberi kesempatan setiap siswa untuk menjawab pertanyaan guru dengan membagi giliran ke setiap siswa. Setiap siswa harus memberi jawaban atas pertanyaan 
guru semampunya. Guru mendemonstrasikan contoh penggunaan alat dan bahan praktikum. Bahkan guru menunjukkan langkah-langkah menggunakan alat dan bahan praktikum secara terperinci. (Fase 1). Guru membantu siswa melakukan pembagian tugas dalam kelompok sehingga setiap siswa terlibat aktif dalam kerja kelompok (Fase 2). Guru membimbing kelompok yang mengalami kesulitan dan memberi motivasi kepada siswa yang pasif dengan memberikan pertanyaan pancingan agar lebih aktif, sehingga diskusi menjadi hidup (Fase 3). Guru memberikan pertanyaan pancingan dalam membimbing siswa membuat kesimpulan hasil percobaan (Fase 4). Pertanyaan pancingan ini sangat membantu siswa dalam membuat kesimpulan secara tepat (Fase 5). Guru juga memberikan kesempatan semua kelompok untuk secara bergiliran menyampaikan pendapatnya.

Hal ini sependapat dengan Arends (2012) bahwa PBL merupakan model pembelajaran yang menyajikan berbagai situasi bermasalah yang autentik dan bermakna kepada peserta didik, yang dapat berfungsi sebagai batu loncatan untuk investigasi dan penyelidikan. Pada siklus II guru juga memberi contoh dan memperagakan penyusunan alat dan bahan eksperimen disertai penjelasan lengkap langkah eksperimen sehingga siswa benar-benar melaksanakan eksperimen dengan tepat dan mandiri. Guru membantu siswa melakukan pembagian tugas dalam kelompok sehingga setiap siswa terlibat aktif dalam kerja kelompok. Guru tak pernah lepas membimbing semua kelompok yang mengalami kesulitan dan memberi motivasi kepada siswa yang pasif dengan memberikan pertanyaan pancingan agar lebih aktif, sehingga diskusi menjadi hidup. Guru senantiasa membimbing siswa membuat kesimpulan hasil percobaan secara tepat. Hal ini sejurus dengan pendapat (Sanjaya, 2016, p. 214), ciri utama strategi pembelajaran berdasarkan masalah adalah: yang pertama, rangkaian aktivitas pembelajaran, artinya peserta didik tidak hanya mendengarkan ceramah dan menghafal namun dititikberatkan pada kegiatan peserta didik dalam berpikir, berkomunikasi, mengolah data, dan menyimpulkan. Kedua, aktivitas pembelajaran diarahkan untuk menyelesaikan masalah. Dalam proses pembelajaran perlu adanya masalah untuk diteliti. Ketiga, pemecahan masalah dilakukan menggunakan pendekatan berpikir secara ilmiah. Proses berpikir ini dilakukan secara sistematis dan empiris.

\section{SIMPULAN}

Berdasarkan hasil pembahasan tindakan kelas yang sudah dilakukan pada kelas VA-2 dengan materi "Sistem Peredaran Darah pada Manusia" di SD Muhammadiyah Nitikan Yogyakarta, dapat ditarik kesimpulan bahwa dari hasil analisis data tes akhir selama dua siklus menunjukkan bahwa hasil belajar IPA siswa dapat ditingkatkan melalui penerapan model pembelajaran Problem-Based Learning (PBL). Perolehan nilai rata-rata pada siklus I adalah 73 meningkat pada siklus II menjadi 82. Ketuntasan belajar pada siklus I adalah 52,78\% meningkat pada siklus II menjadi $75 \%$.

Berdasarkan kesimpulan penelitian tindakan kelas yang dilakukan sebanyak 2 siklus, disarankan sebagai berikut: Guru kelas agar dapat menggunakan model pembelajaran Problem-Based Learning (PBL) sebagai salah satu alternatif untuk meningkatkan kualitas proses pembelajaran dan penguasaan materi dalam pembelajaran IPA. Ada pun langkah-langkah dalam menerapkan metode eksperimen yaitu sebagai berikut: (a) Memberikan orientasi tentang permasalahan kepada peserta didik; (b) Mengorganisasikan peserta didik untuk meneliti; (c) Membantu investigasi mandiri dan kelompok; (d) Mengembangkan dan mempresentasikan hasil karya dan memamerkan; dan (e) Menganalisis dan mengevaluasi proses mengatasi masalah. Sebaiknya melalui kegiatan KKG dapat disosialisasikan dalam pembelajaran IPA hendaknya menggunakan metode eksperimen.

\section{REFERENSI}

Arends, R. I. (2012). Learning to teach (9th Editio). The McGraw-Hill Companies, Inc.

Arikunto, S., Suhardjono, \& Supardi. (2010). Penelitian tindakan kelas. Bumi Aksara.

Patmawati, H. (2011). Analisis keterampilan berpikir kritis siswa pada pembelajaran laruten elektrolit dan nonelektrolit dengan metode praktikum. Jakarta: Lembaga Penelitian UIN Syarif Hidayatullah.

Rakhmawati, Y., Chamdani, M., \& Suryandari, K. C. (2013). Penerapan model PBL dalam peningkatan berpikir kritis IPA siswa kelas V SD. Kalam Cendekia PGSD Kebumen, 3(2). http://jurnal.fkip.uns.ac.id/index.php/pgsdkebumen/article/view/1908/1412 
Sanjaya, W. (2016). Strategi pembelajaran berorientasi standar proses pendidikan. Prenada Media. https://doi.org/2008

Sulistyorini, S. (2007). Model pembelajaran IPA sekolah dasar dan penerapannya dalam KTSP. Tiara Wacana.

Suyitno, A. (2007). Pemilihan model-model pembelajaran dan penerapannya di sekolah. Jakarta: Pusdiklat Tenaga Teknis Keagamaan-Depag. 